\title{
Places in the Indian Ocean World
}

\author{
Michael Pearson
}

To cite this article: Pearson, Michael. "Places in the Indian Ocean World." Journal of Indian Ocean World Studies, 1 (2017), pp. 4-23.

More information about the Journal of Indian Ocean World Studies can be found at: jiows.mcgill.ca

(C) Michael Pearson. This is an Open Access article distributed under the terms of the Creative Commons License CC BY NC SA, which permits users to share, use, and remix the material provide they give proper attribution, the use is non-commercial, and any remixes/transformations of the work are shared under the same license as the original. 


\title{
Places in the Indian Ocean World
}

\author{
Michael Pearson \\ University of New South Wales, Australia
}

We all enact change over time, but are not nearly as concerned with where we are writing about. One recent trend in general historiography may help our maritime studies. This is the matter of place. This could be seen as contributing to the so-called spatial turn in social sciences, including history. Richard White noted:

I don't want to be so simplistic as to say that if space is the question then movement is the answer, but I fear that I am nearly that simple. We produce and reproduce space through our movements and the movements of goods that we ship and information that we exchange. Other species also produce space through their movements. Spatial relations are established through the movement of people, plants, animals, goods, and information. ${ }^{1}$

Or as Peter Stearns put it:

Social historians' decisions about geographic framework, or regionalization, are rarely as explicit as those involving chronological framework, or periodization. This is particularly true in the common tendency to choose national units for topics ranging from family to patterns of work, whether national political factors enter in strongly or not. Subnational selections, for example, the many regional studies in France characteristic of the Annales school, may be more carefully justified in terms of internal coherence and demonstrable distinctiveness, though even here a certain amount of routine may prevail. But the possibility of supranational regionalization, in preference to national choices, is rarely considered. $^{2}$

His colleagues "urge further interdisciplinarity, particularly with geographers and anthropologists who deliberately consider spatial issues, and appropriate attention to

1. Richard White, "What is Spatial History," The Spatial History Project, February 1, 2010, last accessed on March 8, 2017, http://www.stanford.edu/group/spatialhistory/cgi-bin/site/pub.php?id=29.

2. Peter Stearns, "Introduction to a Special Issue on the Future of Social History," Journal of Social History 39, no. 1 (2006): 613-614. 
physical environments."3

To illustrate this, let me say a little about three particular spaces, that is, ships, then coasts, and finally port cities. Most of my data is from the early modern period. On the first, the general point is that if we are to write about what happens on a ship, we need to take into account the size of the vessel. It turns out that things are very cramped, and that where one lived on board was determined by status. But is this all we can say about space on a ship?

Here are just a few examples of space on board various ships. This is by no means a complete study, but it does give an indication of how much room people had. This is an account of a Portuguese ship leaving Lisbon.

Few would find any comfort aboard the great carracks of the Carreira da India. The impressive superstructures that towered up from the stern, which housed the officers and the more affluent, were made up of narrow halfdecks with less than four feet $[122 \mathrm{~cm}]$ between the ceiling and floor, where even fidalgos and bishops scurried about like rats in tomb-like cabins. More fortunate were the captain, the masters, and the pilots, whose cabins usually opened out directly onto the poop deck. hundreds of others had to scramble to claim some corner of their own in the teeming forecastle, or beside a cannon on the gun deck. ${ }^{4}$

The early modern ratio on European ships was roughly one sailor for four or five tons of carrying capacity. ${ }^{5}$ In more detail, for coasting merchant ships the ratio was 15 20 tons per man, and on Royal Navy ships 2-3 tons per man. Merchant ships of course carried cargo and thus had much less room for the crews, but on the other hand the number of crew was much smaller per ton. ${ }^{6}$ For merchant ships the general point is that "usually the accommodation of seamen followed the principle that no valuable cargo space was to be wasted on them..."

When one adds in passengers, things could get very crowded. On Dutch East India Company (VOC) ships that were only forty to fifty metres long, there was on average

3. Ibid.

4. T. Bentley Duncan, "Navigation between Portugal and Asia in the Sixteenth and Seventeenth Centuries," in Asia and the West: Encounters and Exchanges from the Age of Explorations: Essays in Honor of Donald F. Lach, ed. Cyriac K. Pullapilly and Edwin J. Van Kley (Notre Dame: Cross Roads Books, 1986), 3-5. For a contemporary account, see J.H. van Linschoten, The Voyage of John Huyghen van Linschoten to the East Indies, 2 vols. (London: Hakluyt Society, 1885), 2: 231-233.

5. David Kirby and Merja-Liisa Hinkkanen, The Baltic and North Seas (London: Routledge, 2000), 189.

6. N.A.M. Rodger, The Wooden World, An Anatomy of the Georgia Navy (London: Collins, 1986), 26, 44-45, 48-52, 97-98 \& 318-321.

7. Heide Gerstenberger, "Shipboard Life," in The Oxford Encyclopedia of Maritime History, 4 vols. (Oxford: Oxford University Press, 2007), 3: 535. 
180 to 250 on board. ${ }^{8}$ On the Portuguese naus (carracks) bound for India some 600 people would be crammed together, on galleons perhaps $400 .{ }^{9}$ Most travelled in extreme discomfort. Even the elite in the superstructures in the stern were in narrow half decks, with only about a metre between ceiling and floor. Life was extraordinarily cramped and uncomfortable. As Jacques-Henri Bernardin de Saint-Pierre noted on a French ship in 1768 , the crew, "man in the raw," were "lodged under the forecastle and between the decks, a dismal prison where you can see nothing." 10 Similarly, on VOC ships, where one lived revealed hierarchy very clearly. Those on board included the master, other officers such as mates and lieutenants, then petty officers, seafaring craftsmen like the sailmaker, the ship's clerk and the boatswain, and then the majority, the sailors, and on warships soldiers and marines. Captain and officers, and some petty officers, lived and worked in the poop at the stern. Seamen were forward, and soldiers on lower decks. As Jaap R. Bruijn notes, "in short, there was a clear division; each group had its own space." 11 This allocation of space then represents visibly social groupings and social relationships.

We have a number of specific examples to demonstrate this. Nelson's Victory had a crew of 850 on a ship 69 metres in length. The hammocks on the lower gun deck were slung from battens fixed to the overhead beams at intervals of 16 inches (41 centimetres). Although the space was cramped each man's room was effectively doubled because half the crew worked while the others slept. This was for maybe 500 crew members. On the other hand the admiral had a suite of four compartments, a very clear reflection of class distinctions. ${ }^{12}$ Lieutenant Bligh's ship, the famous Bounty, carried 45 men in a ship 91 feet (27.7 metres) long. The great cabin aft, normally reserved for captain's quarters, was extended to a third of the length of the ship in order to house the pots for the breadfruit plants. Planks with holes for the pots formed a second deck within the cabin and the floor was covered with lead sheeting to prevent the excess water from leaking through to the deck below. Pipes were fitted which would lead the water to containers below, so that it could be re-used. All in all there was room for 626 pots in the cabin. A large coal-fired heater was also installed so that the plants would not freeze when the ship was sailing in colder latitudes. ${ }^{13}$ Cook's ship, the Endeavour, had cabins of about two square metres for

8. Jaap R. Bruijn and Els S. van Eyck van Heslinga, "Mutiny: Rebellion on the Ships of the Dutch East India Company," The Great Circle 4 (1982): 1-3.

9. Anthony R. Disney, "The World of Long-Distance Voyaging in the Seventeenth Century: the LisbonGoa fleet of 1629 as a Case Study," in Studies in Maritime History, ed. K.S. Matthew (Pondicherry: Pondicherry University Press, 1990), 146; Linschoten, Voyage of John Huyghen, 1: 10.

10. Jacques-Henri Bernardin de Saint-Pierre, Journey to Mauritius, trans. Jason Wilson (Oxford: Signal Books, 2002), 68 \& 75.

11. Jaap R. Bruijn, "Seafarers in Early Modern and Modern Times: Change and Continuity," International Journal of Maritime History 17 (2005): 2-3.

12. "Images of The Great Cabin on HMS Victory," http://hmsvictory.com/ (site discontinued).

13. "HMS Bounty," Pitcairn Islands Study Center, accessed on March 8, 2017, http://library.puc.edu/ 
him and the Royal Society's representatives, led by Joseph Banks. Each sailor had 35.5 centimetres in which to sling his hammock at night, while an officer had a swinging cot about 46 centimetres of room. ${ }^{14}$

We have rather less information about Asian sailing ships. On the long-distance dhows, the baghlahs and boums, cargo capacities ranged from 150 to 500 tons, and the crews from 20 to 70 men. The ratio is thus 10 seamen to 75 tons. On smaller short distance dhows of 40-75 tons the crew would be between six and 12. This demonstrated substantial economies of scale for bigger ships. ${ }^{15}$ On Alan Villiers' dhow, the Triumph of Righteousness, he shared the poop deck with the captain, mate, the two helmsmen and various merchants. The ship was a boum of about 150 tons, and had a crew of 27 . When one adds in 180 passengers it was very crowded, but he was told that they could have coped with even 250 . He worked out that there was actual deck space, including the poop deck, of 2,200 square feet (204 square metres). This gave each passenger 12 square feet (1.1 square metres) of space, which according to him was much more than they needed. Women were usually not counted, and were secluded in cramped squalid conditions in a cabin beneath the poop. ${ }^{16}$

Two contemporary accounts of other Asian ships show considerable differences. In the early fourteenth century, Ibn Battuta found in Calicut vast array of vessels from Java, Ceylon, the Maldives, Yemen, and Fars. However, the biggest were thirteen Chinese vessels. His eye witness account is of very large ships indeed. He wrote that they were called junks, and had up to 12 sails, and 1000 men on board - 600 sailors, and 400 archers and other soldiers. The oars were as large as the masts on the dhows with which he was familiar, and each was worked by 10 or 15 men. His ship had four decks, with cabins, suites and salons for merchants. Each set of rooms had several rooms and a latrine; it could be locked by its occupant who could take along with him slave-girls and wives. Often a man would live in his suite unknown to any of the others on board until they met upon reaching some town. ${ }^{17}$

pitcairn/bounty/bounty.shtml.

14. "Endeavour," Australian National Maritime Museum, http://www.anmm.gov.au/webdata/resources/ pdfs/vessels/Endeavour.pdf (site discontinued).

15. Yacoub Yusul Al-Hijji, Kuwait and the Sea: A Brief Social and Economic History, trans. Fahad Ahmad 'Isa Bishara (London: Arabian Publishing, 2010), 36, 52 \& 95.

16. Alan Villiers, Sons of Sinbad: An Account of Sailing with the Arabs in the Dhows, in the Red Sea, around the Coasts of Arabia, and to Zanzibar and Tanganyika; Pearling in the Persian Gulf; and the Life of the Shipmasters, the Mariners, and Merchants of Kuwait (New York: C. Scribner's Sons, 1940), 20, 32, 69 \& 71; Al-Hijji, Kuwait and the Sea, 71.

17. Ibn Battuta, The Travels of Ibn Battuta: AD 1325-1354, trans. H.A.R. Gibb (Cambridge: Hakluyt Society, 1994), 4: 813-814. However, in Roderich Ptak, "China and Portugal at Sea: The Early Ming System and the Estado da India Compared," Revista de Cultura 13/14 (1991): 24, the author notes that it seems dubious that Chinese ships in the fifteenth century were over 100 metres long. See also Ma Huan, 
Finally, Alexander Hamilton left us an account of ships on the Indus river, which was navigable a long way up. Hamilton wrote

their Vessels are called Kifties \{?], of several Sizes. The largest can lade about 200 Tuns. They are flat-bottomed, and, on each Side, Cabbins [sic] are built from Stern to Stem, that overhang about 2 Foot; and, in each Cabbin, is a Kitchen and a Place for Exoneration, which falls directly in the Water. ${ }^{18}$

So much for some random accounts of sizes and accommodations. The obvious point is that space on early modern ships was limited and reflected class divisions. As we look at the social space of an early modern ship in the Indian Ocean, space itself is crucial. Greg Dening suggests that what happened on the Bounty was directly related to the ship's spatial organisation. Indeed, Dening in general notes "much of my work concerns spaces, symbolic and real, and how they shape human behaviour." ${ }^{19}$ Doreen B. Massey has written extensively on this also. ${ }^{20}$ Arrangements of space make important symbolic statements about social groupings and social relationships, or as Georg Simmel put it in 1896: "all social interactions could be characterized by their relative degree of proximity and distance among individuals and groups." ${ }^{21}$ In The Production of Space, Henri Lefebvre contends that there are different levels of space, from very crude, natural space ("absolute space") to more complex spatialities the significance of which is socially produced ("social space"). ${ }^{22}$ We can also note that Michel Foucault, in his study of space entitled, "Different Spaces," finishes with a nostalgic glance back at the great colonial era of sea travel and the ship as an extreme type of heterotopia:

A piece of floating space, a placeless place, that lives by its own devices, that is self-enclosed and, at the same time, delivered over to the boundless expanse of

The Overall Survey of the Ocean's Shores, trans. J.V.G. Mills (Cambridge: Hakluyt Society, 1970), 303-310. For comprehensive discussions of this subject, see Joseph Needham, Science and Civilization in China, 4 vols. (Cambridge: Cambridge University Press, 1954-2000), esp. volume 4, part 1 and 3; and Gang Deng, Chinese Maritime Activities and Socioeconomic Development, c. 2100 B.C.-1900 A.D. (Westport: Greenwood Press, 1997).

18. Alexander Hamilton, A New Account of the East Indies, 2 vols. (London: Argonaut Press, 1930), 1:

76.

19. Greg Dening, "Deep Times, Deep Spaces: Civilizing the Sea," in Sea Changes: Historicizing the Ocean, ed. Bernhard Klein and Gesa Mackenthun (New York: Routledge, 2004), 21.

20. Doreen B. Massey, Space, Place, and Gender (Minneapolis: University of Minnesota Press, 1994).

21. David Fearon, "Georg Simmel, The Sociology of Space," CSISS Classics, 2004, accessed on March 8, 2017, http://escholarship.org/uc/item/7s73860q\#page-1

22. Henri Lefebvre, The Production of Space, trans. Donald Nicholson-Smith (Oxford: Blackwell, 1991). 
the ocean, and that goes from port to port, from brothel to brothel, all the way to the colonies in search of the most precious treasures that lie waiting in their gardens, you see why, for our civilisation, from the sixteenth century up to our time, the ship has been at the same time not only the greatest instrument of economic development $\ldots$ but the greatest reservoir of the imagination. ${ }^{23}$

These comments may help us go beyond the obvious matters of cramped space, and reflections of social divisions. For example, in Dening's seminal account of the infamous mutiny on the Bounty, he argues that the tensions which erupted among the crew in the Pacific had their roots in the specific geography of the ship, or at least the way in which the spaces of the vessel were understood by the crew and the ship's officers. ${ }^{24}$ On Bligh's ship 45 men were crowded into a ship 27.7 metres long and seven metres wide. ${ }^{25}$ Even Bligh lacked room to stretch, for the great cabin was taken over for breadfruit pots. Dening's point was that this physical matter had important consequences for the voyage of the Bounty. Ships are constructed and arranged to present a conventional, ordered social hierarchy: place, space and power are traditionally aligned. Bligh was deprived of the very spatial symbolism of the authority (albeit that he was a lieutenant rather than captain) he was expected to wield. ${ }^{26}$

Dening notes in one pithy observation that "space and the language used to describe it make the ship." ${ }^{27}$ Indeed in the case of the Bounty he suggests that the antagonisms which emerged aboard the ship reflected a strict spatialised hierarchy, and the discourse enacted to support it. ${ }^{28}$

Here is one statement by Robert Foulke about the difference between land and sea spaces:

Once committed to the open sea, human beings are enclosed irrevocably by the minute world of the vessel in a vast surround. That world reverses many physical and social realities. Ashore, healthy human beings desire bodily movement and gain a sense of freedom and power through it, notably in activities like walking, running, dancing, or skiing. At sea, motion is imposed

23. Michel Foucault, Madness and Civilization (London: Routledge, 1989), 184-185.

24. William Hasty and Kimberly Peters, "The Ship in Geography and the Geographies of Ships," Geography Compass 6, no.11 (2012): 664.

25. "HMS Bounty," Pitcairn Islands Study Center, accessed on March 8, 2017, http://library.puc.edu/ pitcairn/bounty/bounty.shtml.

26. Michael Titlestad and Pamila Gupta, "Introduction: The Story of the Voyage," South African Historical Journal 61, no.4 (2009): 674.

27. Greg Dening, Mr. Bligh's Bad Language: Passion, Power and Theatre on the Bounty (Cambridge: Cambridge University Press, 1992), 19.

28. Ibid., 81. 
upon one, with temporary but debilitating effects. Again, many individuals ashore can join or leave groups at will, but at sea, all are compressed within a single, unchanging, society and one traditionally and sensibly marked by a rigid hierarchy at that. It is often possible to choose a solitary life ashore, or at least to regulate contact with others, but at sea, the absolute isolation of the vessel makes adapting to the fixed society on board unavoidable. In this fragmentary but self-contained world, seafarers have time on their hands ... they live on an unstable element that keeps their home in constant motion, sometimes soothing them with a false sense of security, sometimes threatening to destroy them. ${ }^{29}$

So also from Rabindranath Tagore:

It seems that the ship has torn off a slice of the domestic world as it sailed away from the shore. On land people have the chance of preserving distance between one another; but the space here is limited, people live in close proximity. And yet it is hard to know them. Every time before boarding the ship this thought oppresses my mind - this distance of the nearness, this association without companionship. ${ }^{30}$

It could be that this depicts far too much of a gap between ship and shore and perhaps "we should keep in mind that, at the time, the space allocated was more or less equal to the conditions that many farmhands and servants ashore had to make do with." 31 Similarly, as noted by Sarah Moss, several historians have commented that ships are what the sociologist Erving Goffman has defined as 'total institutions', places such as asylums and prisons where inmates are completely enclosed and, within that enclosure, completely public. A total institution may be defined as a place of residence and work where a large number of like-situated individuals, cut off from the wider society for an appreciable period of time, together lead an enclosed, formally administered round of life. Although the idea of the total institution has been challenged and complicated, in the case of ships at sea - where the very simple and important binary construction of on board/overboard is always valid - it remains fruitful. ${ }^{32}$

Bernhard Klein and Gesa Mackenthun note that there is "a new interest in the

29. Robert Foulke, "Odysseus's Oar," in Maritime History as World History, ed. Daniel Finamore (Gainesville: University Press of Florida, 2004), 190-191.

30. Rabindranath Tagore, The Diary of a Westward Voyage, trans. Indu Dutt (Bombay: Asian Publishing House, 1962), 12.

31. Gerstenberger, "Shipboard Life," 535.

32. Goffman in Sarah Moss, "Class War and the Albatross: The Politics of Ships as Social Space and The Rime of the Ancient Mariner," in Fictions of the Sea: Critical Perspectives on the Ocean in British Literature and Culture, ed. Bernhard Klein (Aldershot: Ashgate, 2002), 79-80. 
living conditions and cultural experiences of men and women who go to sea." ${ }^{33}$ They quote from Paul Gilroy's Black Atlantic ${ }^{34}$ that the ship is "a living, micro-cultural, micropolitical system in motion" and go on to say, "In the light of much of this innovative research, oceans and ships can now be newly assessed as spaces and sites of cultural conflict as well as, crucially, though less obviously visible, of cooperation." ${ }^{35}$ So we need to shift "our attention away from continents as defining geographical entities to the ocean itself as a hybrid cultural space." ${ }^{36}$

In sum, it is clear that a consideration of space can lead far beyond the obvious matters of cramped conditions and revelations of hierarchy to point to the possibilities of a holistic view of the ship, finding both cooperation and conflict, seeing the whole aquatic society as a cultural system, and looking at the spatial symbolism of the ship.

Let me now turn to a different sort of space, this one geographic. ${ }^{37} \mathrm{I}$ have written quite extensively on littoral society as a transitional and fungible zone, neither land nor water. ${ }^{38}$ What I would like to add now is the concept of an ecotone, which is a biological term meaning a zone of transition between adjacent ecological systems, or where two or more ecosystems meet. The argument is that for most of history the coast was a classic ecotone, land and sea mixing; however over the last two centuries, roughly, the coast has been territorialised, and the ecotone transformed or destroyed.

The concept of an ecotone has been on the agenda for some time now, and is widely used by biologists and environmental scholars. This neologism is a combination of eco(logy) and tone, from the Greek for tension. It is thus a place where ecologies are in tension, or more generally an ecotone is a transitional area between two or more ecological communities. Ecotones occur over a broad spectrum of space and time scales. They may be narrow or broad, and can be on the one hand local, as in the zone between a field and forest, or regional, such as the transition between forest and grassland.

Crucially, chronology is central and must be taken into account in what Richard

33. Bernhard Klein and Gesa Mackenthun, "Introduction: The Sea is History," in Sea Changes: Historicizing the Ocean, ed. Bernhard Klein and Gesa Mackenthun (Aldershot: Ashgate, 2002), 4.

34. Paul Gilroy, The Black Atlantic: Modernity and Double-Consciousness (Harvard: Harvard University Press, 1995).

35. Ibid.

36. Ibid.

37. What follows owes a huge debt to John Gillis, both for his publications, and for correspondence and friendship over the last decade. The present section draws on my presentation to a conference organized by Rila Mukherjee titled "Territoriality in Coastal Societies" held in Kolkata in January 2015.

38. Michael Pearson, "Littoral Society: The Concept and the Problems," Journal of World History 17, no.4 (2006): 353-373. 
White called 'movement'. Identification of an ecotone depends on the time over which the interactions of two habitats are observed. A transition zone between land and water varies at the scale of days, seasons, years, and decades. A riverine ecotone may appear narrow during the summer, broader if an annual cycle is considered, and very large if a flood of a century and its effects are included. Many other, including spatial, characteristics will change accordingly.

The ecotone in which I am interested is of course the coast, the littoral, the marge. This is defined as "[a]n edge or border of something; esp. a river bank, shore." ${ }^{39}$ This leads me to note that the terrestrial version of this is marche, and I will say a little about this as we find the marche area has now disappeared. A marche is of course a historical and political version of an ecotone, and its end is mirrored in the end of the shore as an ecotone, my main subject which I will come to in a minute.

A marche is the buffer which premodern states left between themselves, thus an ecotone, a transitional area between two states. In this case the ecotone is of course political rather than biological or environmental. A few examples will suffice to show how premodern states did not have the fixed linear boundaries which we find today. As Zoltán Biedermann notes,

The kingdoms of Sri Lanka in the sixteenth century defined themselves by their capacity to 'irradiate' power from central places across an often sparsely populated inland space. As Sheldon Pollack put it with regard to Indian empire-building, it was not so much the centre that expanded to establish itself militarily and administratively (i.e. territorially) in increasingly distant regions ... but rather those distant places that, at one moment or another would accept to pay homage to a polity styling itself as a politically and culturally attractive centre. ${ }^{40}$

No need to labour this point, but a glance at sultanate Gujarat will reinforce the point that the borders of this state were not clearly defined, but rather were a marche, an ecotone. Gujarat in fact was two areas. One was what the more aware Portuguese called Cambay, the area around the Gulf of Cambay up to the 50 metre contour line. This was held quite firmly, and under the Mughals paid land revenue. Beyond this was a large region where the ruling Rajputs paid only tribute, and only when they were compelled. This difference is reflected in the terminology used in the Persian chronicles, where the central area is a vilayat, and the bordering areas are usually described as appendages, muzafat. ${ }^{41}$

39. Oxford English Dictionary, $3^{\text {rd }}$ ed., s.v. "marge."

40. Zoltán Biedermann, The Portuguese in Sri Lanka and South India: Studies in the History of Diplomacy, Empire and Trade, 1500-1650 (Wiesbaden: Harrassowitz, 2014), 81.

41. Michael Pearson, Merchants and Rulers in Gujarat (Berkeley: University of California Press, 1976), 61-64. 
Compare this situation in Sri Lanka and Gujarat, and indeed any other premodern "state," with the voracious demand for loyalty of the modern nation state.

Turning to the shore, we can be a little more specific. Marine biologists divide the intertidal region into three zones (low, middle, and high), based on the overall average exposure of the zone. The low intertidal zone, which borders on the shallow subtidal zone, is only exposed to air at the lowest of low tides and is primarily marine in character. The mid intertidal zone is regularly exposed and submerged by average tides. The high intertidal zone is only covered by the highest of the high tides, and spends much of its time as terrestrial habitat. The high intertidal zone borders on the splash zone (the region above the highest still-tide level, but which receives wave splash). On shores exposed to heavy wave action, the intertidal zone will be influenced by waves, as the spray from breaking waves will extend the intertidal zone. ${ }^{42}$

I have often used the concept of ressac when I writing about the shore. The term comes from Jean-Claude Penrad. It is the three-fold violent movement of the waves, turning back on themselves as they crash against the shore. Penrad uses this image to elucidate the way in which the to-and-fro movements of the ocean mirror coastal and inland influences which keep coming back at each other just as do waves. We are describing a classic ecotone. And one other example. Françoise Vergès writes of "the endless movements of the waves on the island's coasts, bringing new elements while taking away old elements. The line of the coast is slowly changed, erosion takes its toll, but the ocean with its movement adds new deposits." ${ }^{33}$ Or consider this: Kuntala LahiriDutt and Gopa Samanta write about chars, islands in the Damodar River which emerge due to deposits of alluvium. They can appear and disappear very quickly, and so make a very uncertain environment for their settlers. These are in-between places, neither land nor water. ${ }^{44}$

Before the anthropocene era, that is up to about 200 years ago, coastal inhabitants were both terrestrial and maritime. This was an amphibious culture. Michel Mollat discusses the harvesting of seaweed, or kelp, to make fertilizer, and today also to provide various elements of some foodstuffs. But, he says, this activity, located by definition right on the sea shore, does not turn the farmer who cuts it into a mariner: rather he is both landed and maritime. So also with the person who harvests pebbles for building materials, or collects sand to make glass, or mines salt on the sea shore. ${ }^{45}$

42. See James M. Acheson, “Anthropology of Fishing," Annual Review of Anthropology 10, no.1 (1981): 275-316.

43. Françoise Vergès, "Indian-Oceanic Creolizations: Processes and Practices of Creolization on Réunion Island," in Creolization: History, Ethnography, Theory, ed. Charles Stewart (Walnut Creek: Left Coast Press, 2010), 133-152. My thanks to Fernando Rosa for this reference.

44. Kuntala Lahiri-Dutt and Gopa Samanta, Dancing with the River: People and Life on the Chars of South Asia (New Haven: Yale University Press, 2013).

45. Michel Mollat du Jourdin, Europe and the Sea (Oxford: Blackwell, 1993), 133. 
J.C. Heesterman stressed that "the littoral forms a frontier zone that is not there to separate or enclose, but which rather finds its meaning in its permeability." 46 Fernand Braudel wrote evocatively about coastal society, stressing that it was as much land as sea oriented. The life of the coast of the Mediterranean is

...linked to the land, its poetry more than half-rural, its sailors may turn peasant with the seasons; it is the sea of vineyards and olive trees just as much as the sea of the long-oared galleys and the round-ships of merchants, and its history can no more be separated from that of the lands surrounding it than the clay can be separated from the hands of the potter who shapes it. ${ }^{47}$

John Gillis has a lot to say about this in his excellent Human Shore. Fishers and farmers overlapped. "Fishing and farming, game keeping and gardening, had developed in tandem ... Fish and shell fish combined with animal flesh and edible plants to produce food." ${ }^{8}$ Or "native Americans had one boot in the boat, another in the field."

Thus the concept of an ecotone can be extremely fruitful, not only to describe the coast before the anthropocene era, but also to illuminate what has subsequently happened. Where once people of the shore could be both farmers and fishers, they now are one or the other, not both. Similarly, the sea has been territorialised, or perhaps continentalised, as seen in the creation of exclusive economic zones (EEZ's), thus ending centuries where the sea was mare nullius, part of the commons.

As a ruler of Makassar said, "God made the land and the sea; the land he divided among men and the sea he gave in common. It has never been heard that anyone should be forbidden to sail the seas." ${ }^{50}$ Indeed, Hugo Grotius wrote the ocean "can be neither seized nor enclosed; nay, which rather possesses the earth than is by it possessed." 51 Over the last 200 years this has been reversed. Sea has become continentalised. Land has for long been parcelled and divided and clearly owned as either private or official property. Now this is happening to the sea as states extend their fishing limits and exclusive economic zones. This can be enforced because modern planners, using satellite navigation techniques, can now draw lines in the ocean to show boundaries, just like on land.

46. J.C. Heesterman, “Littoral et Intérieur de l'Inde," Itinerario 4, no. 1 (1980): 89.

47. Fernand Braudel, The Mediterranean and the Mediterranean World in the Age of Philip II, 2 vols. (London: Collins, 1972), 1: 17.

48. John Gillis, The Human Shore: Seacoasts in History (Chicago: University of Chicago Press, 2012), 25.

49. Ibid., 89.

50. Anthony Reid, "The System of Trade and Shipping in Maritime South and Southeast Asia, and the Effects of the Development of the Cape route to Europe," in The European Discovery of the World and its Economic Effects on Pre-Industrial Society, 1500-1800, ed. H. Pohl (Stuttgart: F. Steiner, 1990), 73.

51. Hugo Grotius, The Freedom of the Seas (Oxford: Oxford University Press, 1916), 94. 
There are other ways to see the end of the ecotone. As I noted, coastal inhabitants used to be amphibious. Sailors usually came from the same families for many generations. Now sailors are really just labourers who work at sea, who could as well be in a building site, or in a factory. Alan Villiers, a man with vast experience under sail, in 1922 worked on a steam ship. The work was boring and repetitive, so that being a seaman on it was 'merely another form of labouring. Similarly, traditional fishing communities are now displaced by vast factory fishing boats. The crews on the vast tankers, container ships, and bulk carriers, are a mere handful compared with those on earlier sailing ships. My interviews with officers who serve on these ships revealed almost no whiff of ozone. Rather they often take their families with them. The food on these behemoths is identical to what they would eat on land, with barbeques every Friday. Satellite TV and video movies again replicate the landed experience. Modern cargo handling methods, roro (roll on roll off), mean that these ships and their crews spend very little time in port - a matter of hours sometimes, at most a few days. In fact often no one goes ashore. At the huge jetties loading bulk carriers or oil tankers the ship hovers off shore, connected to the land only by a rail line or a pipe line. Thus the traditional port city, with its bars and brothels, has all but vanished. Sea ports are no longer part of a wider coastal zone with distinctive populations. In fact seaports today are coastal only in terms of location. The waterfront is no longer an ecotone where environments connect with, challenge, and reinvigorate one another. ${ }^{52}$

Maybe the best indication of the tearing apart of the ecotone, the dominance of territory, land, over water, is to look at who lives on the coast today. Once inextricably tied to the sea, and deriving a livelihood from it, now the sea faring population has declined. The coast is inhabited by thoroughly landed people, so that the coast as ecotone has disappeared because one ecosystem, the land, has overwhelmed the other, the sea. To quote Gillis,

and in the twentieth century the sea's side became everywhere seaside, shaped by the needs and desires of landlubberly peoples. Today, populations around the world surge toward the sea, not to produce but to consume. The numbers of whose making their living from the sea is shrinking, even as the coastal population explodes..$^{53}$

And again,

The world has been losing one kind of coast and gaining another, one much

52. Gillis, The Human Shore, 17.

53. John Gillis, "From Ecotone to Edge: Atlantic Coasts, 1450-1850," (paper presented at the Age of Sail Conference, Vancouver, British Columbia, October 2010). 
less connected to its natural environment, the ecotone that sustained coastal people for millenia. The new coast is a product not of nature but of design. It is an anthropogenetic coast, engineered to the specifications of both the inland populations who now colonise the shore and the deep-sea fishing and shipping industries, which operate according to the same temporal and spatial specifications as their more terrestrial counterparts. ${ }^{54}$

I hope that taking space seriously, always though insisting on movement and change, that is chronology, can contribute to a more sophisticated understanding of how the coast has been territorialised. The concept of an ecotone turns out to be very useful as we try to understand how the spatial area of the coast has changed over the last 200 or so years. If we take on board the notion of an ecotone and trace it over time we can gain a better understanding of how its demise can be understood. So also with space on an early modern ship. If we move beyond obvious matters of cramped conditions and reflections of social differences, we may be able to move to a holistic view of ship society.

Finally, what about port cities as places? We have frequently been told that these are characterised by cosmopolitanism. Thus according to Rhoads Murphey, the great authority, "The true port city by definition links very distant maritime spaces, and this is the reason for what is perhaps its most noticeable characteristic. Ports are inclusive, cosmopolitan, while the inland is much less varied, much more exclusive, single faceted rather than diverse." ${ }^{55}$ As Murphey noted,

Port functions, more than anything else, make a city cosmopolitan ... A port city is open to the world, or at least to a varied section of it. In it races, cultures, and ideas as well as goods from a variety of places jostle, mix, and enrich each other and the life of the city. The smell of the sea and the harbour, still to be found ... in all of them, like the sound of boat whistles or the moving tides, is a symbol of their multiple links with a wider world, samples of which are present in microcosm within their own urban areas." 56

Mariam Dossal claims that in Bombay everyone was cosmopolitan. All of the actors and participants from high to low "were touched by the spray of the Arabian Sea, the spray that carries the fragrance of other countries, of other cultures." 57

54. Gillis, The Human Shore, 164.

55. Rhoads Murphy, "On the Evolution of the Port City," in Brides of the Sea: Port Cities of Asia from the 16th-20th Centuries, ed. Frank Broeze (Sydney: New South Wales University Press, 1989), 225.

56. Ibid.

57. Mariam Dossal, “The Call of the Sea: Maritime Mumbai, c. 1660-2000”, in Ports, Towns, Cities: A Historical Tour of the Indian Littoral, ed. Lakshmi Subramanian (Mumbai: Marg Publications, 2008), 
Let me start by defining the crucial term cosmopolitan. One is that cosmopolitanism is an affiliation to humanity-in-general. As such it is often defined as a globalist orientation, associated with elite cosmopolitanites. Yet cosmopolitanism is also embedded in social relations and in civil societies. It can have a powerful insurgent quality, and capacity to disrupt elitism, if not unseat it. Dominant cosmopolitanism, in the singular, is thus displaced by "other cosmopolitanisms," in the plural. Two anthropologists, whose work attempts to counter overly ambitious claims of cosmopolitanism in the Indian Ocean, say

... the term clearly, and etymologically, refers to the idea of being part of a broad social project that exists outside the confines of kinship, ethnicity or nationality. Importantly ... 'cosmopolitanism' envelops a consciousness of human diversity ... Thus, in one sense, cosmopolitanism can be seen as normative 'goal' to live in peace with one another and willingly subscribe to the same basic principles. In another sense, cosmopolitanism can also be seen as a factual 'challenge': how to create or envisage wider unity when faced with social diversity. ${ }^{58}$

In brief, a population is cosmopolitanism if it can view its place in a greater, even global, frame. Or as Shanti Moorthy has it, "cosmopolitanism refers to a subjective consciousness of ethnic heterogeneity occurring within a specific geographical locale." 59 For authors Glenda Sluga and Julia Horne,

Cosmopolitanism, defined as both 'a way of being in the world' and 'the substantive utopian ideal of a polis or polity constructed on a world scale, has been a major field of social inquiry in philosophy, social theory, sociology, and cultural studies for more than a decade. But if historians have been slow off the mark, they are quickly making up ground. ${ }^{60}$

Rosa Maria Perez in her outstanding study of Goa notes how "cosmopolitanism" has inserted itself into the academic agenda, and goes on to point out that

from early times Goans used the intercontinental networks of the Portuguese

144.

58. Edward Simpson and Kai Kresse, "Introduction - Cosmopolitanism Contested: Anthropology and History in the Western Indian Ocean," in Struggling with History: Islam and Cosmopolitanism in the Western Indian Ocean, ed. Edward Simpson and Kai Kresse (London: Hurst, 2008), 2-3.

59. Shanti Moorthy, "Abdulrazak Gurnah and Littoral Cosmopolitanism," in Indian Ocean Studies: Cultural, Social, and Political Perspectives, ed. Shanti Moorthy and Ashraf Jamal (London: Routledge, 2010), 73.

60. Glenda Sluga and Julia Horne, "Cosmopolitanism: Its Pasts and Practices," Journal of World History 21, no.3 (2010): 369. 
empire as means to circulate, both to other colonies (mainly through the channels of the colonial administration, commerce, medicine and law) and to Portugal. ${ }^{61}$

She then quotes Pnina Werbner: "At its most basic, cosmopolitanism is about reaching out across cultural differences through dialogue, aesthetic enjoyment, and respect, of living together with difference..."62

Essentially cosmopolitanism would have to transcend the great diversity of people we find in early modern Indian Ocean port cities. Elsewhere I have discussed how people from very different linguistic groups were able to communicate, this being essential for cosmopolitanism to exist. ${ }^{63}$ To summarise, there was silent trade, using the services of a resident from the same group in a distant port city, temporary marriage to a local woman, specialist brokers who controlled several different languages, and finally the possibility of a lingua franca, first Arabic and then Portuguese, found all around the shores of the ocean. The point however is while these mechanisms existed, they were used by very few people in early modern Asia, even indeed in the purportedly cosmopolitan port cities. Most people did not move. Most trade was local, not international. Even people who travelled remained embedded in their original culture, not necessarily taking part in other cultures.

I must here acknowledge the recent work of Francesca Trivellato, who has done so much to show how precisely the sort of communication I am writing about was achieved in the case of Ashkenazi Jews. The recent book edited by Francesca Trivellato, Leor Halevi, and Cátia Antunes goes much further, investigating other elements such as the political, economic, and juridical underpinnings of cross-cultural trade. My very limited observations ignore such matters as differing legal regimes, and cultural matters like food restrictions, marriage differences, and different religious practices. ${ }^{64}$ Lamin Sanneh noted that

61. Rosa Maria Perez, The Tulsi and the Cross: Anthropology and the Colonial Encounter in Goa (New Delhi: Orient Blackswan, 2011), 4.

62. Pnina Weber, "Introduction: Towards a New Cosmopolitan Anthropology," in Anthropology and the New Cosmopolitanism: Rooted, Feminist and Vernacular Perspectives, ed. Pnina Weber (New York: Berg, 2008), 2.

63. See Michael Pearson, "Ocean of Stories: Communication in the Early Modern Indian Ocean World," Transforming Cultures eJournal 4, no. 2 (2009): 18-28.

64. Francesca Trivellato, The Familiarity of Strangers: The Sephardic Diaspora, Livorno, and Cross-Cultural Trade in the Early Modern Period (New Haven: Yale University Press, 2009); Francesca Trivellato, "Jews of Leghorn, Italians of Lisbon, and Hindus of Goa: Merchant Networks and Cross-Cultural Trade in the Early Modern Period," in Commercial Networks in the Early Modern World, ed. Diogo Ramada Curto and Anthony Molho (Florence: European University Institute, 2002); Francesca Trivellato, "Introduction: The Historical and Comparative Study of Cross-Cultural Trade," in Religion and Trade: Cross-Cultural Exchanges in World History, 1000-1900, ed. Francesca Trivellato, Leor Halevi, and Cátia Antunes (Oxford: Oxford University Press, 2014), 1-23. 
...the visitors are very different from inland peasant populations. These are some of the most enterprising and dynamic individuals, people whose horizons have been broadened by time and exposure, whose skins wear the deep hue of the 'tanning of travel.' They bring awareness of an enlarged macrocosm to their host community, transfusing resident populations with new ideas in the give of foreign expertise and the take of local hospitality. ${ }^{65}$

Yet there is reason to question the basic assumption that travel broadens the mind, and makes participants more amenable to new experiences. Rather it seems that most travellers firmly retained their native habits and prejudices. Finally, it is a possibly unsustainable assumption to say that the movement of goods and people inevitably leads to interaction and cosmopolitanism.

We need to think carefully about a recent comment from Edward Simpson and Kai Kresse, who wrote that

It seems to us that contrary to some prevailing notions of Indian Ocean historicity, human connectivity in the region (that is to say connections across the Indian Ocean) tends actually to be rather limited. Some scholars have taken the movement of goods through the ports of the region as an axiomatic sign of cosmopolitanism. Here, there seems to be a general confusion of people and things because while some goods have wonderful migration histories, the individuals who traded such items tended to act merely as nodal brokers between different legs of the goods' journey and only travelled occasionally, perhaps seasonally, themselves. There is however more at stake here than the idea that goods moved a great deal and people moved much less. In our view, what movement and migration there was (and is) tended to create new or modified divisions in the population both at home and away rather than creating a unified oceanic society. ${ }^{66}$

In a similar vein, Muslim authorities travelled widely spreading and rectifying the Faith. However, Richard Eaton notes sufis coming to Bijapur from Arabia and Iraq who firmly retained their own customs and habits, who continued to write in Arabic, made many pilgrimages, and sent gifts back to Mecca. One Arab pir (sufi master or spiritual advisor) even brought his own Arab murids (sufi initiates) with him. ${ }^{67}$ So also with the

65. Lamin Sanneh, "Time, Space, and Prescriptive Marginality in Muslim Africa: Symbolic Action and Structural Change," in World History: Ideologies, Structures, and Identities, ed. Philip Pomper (Oxford: Oxford University Press, 1998), 128.

66. Simpson and Kresse, Cosmopolitanism Contested, 13.

67. Richard M. Eaton, Sufis of Bijapur, 1300-1700: Social Roles of Sufis in Medieval India (Princeton: 
hajj, in theory the great unifier and consolidator of the Faith. Yet, only a small percentage of the total Muslim population of any country ever performed the hajj. Nor did the actual hajj experience necessarily lead to inter-ethnic mingling and fellowship. Each ethnic and linguistic group in fact had their own hajj guide, their mutawwif, who operated as a de facto boss serving among other things to keep people in their own groups.

Consider other examples of chauvinism and intolerance from travelling Muslim scholars and authorities, who were far from seeing all members of the Faith as "brothers" or equal members of the "umma (Muslim community). Ibn Battuta treated the rustic Muslims he found on the Swahili coast and in Malabar with some contempt, criticizing their knowledge of Arabic. He is merely one example of a self-proclaimed expert from the heartland, or near enough, who had a pronounced air of superiority as he mingled with the indigenous Muslims around the ocean. His praise is reserved for those who like himself were Arabs from the heartland, and indeed he always commented on their presence, and praised them, while either ignoring or belittling the locals. Typical was his experience in the Kerala backwaters when he was travelling from Calicut to Quilon. The trip took ten days, and they anchored at night and stayed in villages. It was not a pleasant trip. "There was no Muslim on board the boat except the man I had hired, and he used to drink wine with the infidels when we went ashore and annoy me with his brawling." ${ }^{8}$

So also with Ibn Jubayr, who left us a long passage of invective against the black Muslims of the west shore of the Red Sea. ${ }^{69}$ Within the Muslim "community", there was considerable dubiety expressed by those from the heartland of the Middle East to those on the edges, as in the Malay world, or even in Gujarat. The great navigator Ibn Majid wrote of his ostensible co-religionists in the Malay world that "they are evil people who follow no rules; the unbeliever marries the Muslim, and the Muslim the infidel woman... they publicly drink wine, and they do not pray before setting out on a voyage." ${ }^{70}$ An unsuccessful Ottoman grandee in 1538 said that the local Gujarati Muslims were very slack: "at the time of prayer they simply play music; most of them are infidels..."71

This also applies to Christian groups. The whole object of the Inquisition was to reduce flexibility and tolerance in the Christian community, and impose a very narrow, Council of Trent type of Catholicism. And we know that Hindu and Jain merchants

Princeton University Press, 1978), 127.

68. Battuta, Travels, 4: 816.

69. Muhammed ibn Ahmad Ibn Jubair, The Travels of Ibn Jubayr (1183-1185 AC), trans. R.J.C.

Broadhurst (London: Jonathan Cape, 1952), 66.

70. Luis Filipe F.R. Thomaz, "Malaka et ses communautés marchandes au tournant de 16e siêcle," in Marchands et hommes d'affairs asiatiques dans L'Océan Indien et la Mer de Chine 13e-20e siêcles, ed. Denys Lombard and Jean Aubin (Paris: Éditions de l'École des hautes études en sciences sociales, 1988), 42.

71. Michael Pearson, Pious Passengers: the Hajj in Earlier Times (New Delhi: Concept Publishers, 1994). 
seem to have practiced the sort of rigid caste discrimination still encountered today. Simpson and Kresse note that migration and trade could solidify boundaries suggested by caste and religion. They instance several Muslim and Hindu groups where increased exclusiveness has resulted from moving to new areas. ${ }^{72}$ In sum, I tend to like the following aphorism from the Roman lyric poet Horace: "Caelum non animum mutant qui trans mare currunt"73 ("Those who cross the sea change the sky, but not their souls").

Fernando Rosa asked me to consider that "constitutive cosmopolitanism" is a main feature of the port city - namely the distinction between the "indigenous" and the "foreign" is possibly not the main axis of local society even though it may exist under some form. ${ }^{74}$ This is a bold claim indeed, and given our fragmentary sources really impossible to prove or dispute. Concentrating on Indian Ocean port cities in the pre-colonial period, which I take to go up to about 1750, we simply do not have the demographic data to enable any definitive pronouncement to be made. Indigenous and foreign? But what is a foreigner? There was a vast array of different people in the great port cities, such as Surat, but are these all foreign? A Mughal from the heartland of the empire? An Arab from Hadramaut? A Bengali? A king from Coromandel? Is it a linguistic matter: if you speak Gujarati you are indigenous, if any other language you are foreign? But then surely, excuse my introducing some political economy matters, class is important. A Gujarati merchant speaking several languages and dealing often with non-Gujaratis is surely much more cosmopolitan than say a weaver or porter speaking only Gujarati. Travellers' accounts make it clear that visiting Europeans mingled and had intimate, albeit often adversarial, relations with other merchants and brokers, but it could be argued that they had no contact with the vast bulk of the perhaps 200,000 residents of Surat. To include everyone in early modern Surat or Cochin or Melaka in a notion of constitutive cosmopolitanism may well be too ambitious an aim.

Maybe even seamen, travellers though they are not really cosmopolitan, rather set themselves apart. Some of them never went ashore. Joseph Conrad wrote that

most seamen lead if one may so express it, a sedentary life. Their minds are of the stay-at-home order, and their home is always with them - the ship; and so is their country - the sea... For the rest, after his hours of work, a casual stroll or casual spree on the shore suffices to unfold for him the secret of a whole continent, and generally he finds the secret not worth knowing. ${ }^{75}$

72. Simpson and Kresse, Cosmopolitanism Contested, 13-14.

73. See Daines Barrington, “Observations on the Apamean Medal” in Archaeologia: Or Miscellaneous Tracts Relating to Antiquity 4 (1777), 324.

74. Fernando Rosa, email message to the author, October 2, 2012.

75. Joseph Conrad, Heart of Darkness (Blackwood's Magazine, 1899). 
An even more ship-bound figure, again from Conrad, was "Singleton, who had sailed to the southward since the age of twelve, who in the last forty-five years had lived (as we had calculated from his papers) no more than forty months ashore..." ${ }^{\prime 6}$ Such men were called "shellbacks," used to describe an experienced sailor, the idea being that he had been at sea so long that limpets and barnacles had grown on his back.

Fiction to be sure, but consider also sailors in Siraf around 1000. A few of the merchants of this great port travelled so much that they were away at sea all their lives. The contemporary account goes on:

I was told of one man of Siraf who was so accustomed to the sea that for nearly forty years he did not leave his ship. When he came to land he sent his associates ashore to look after his business in all the towns, and he crossed over from his boat to another, when the vessel was damaged and needed to be repaired. ${ }^{77}$

So maybe the notion of a cosmopolitan culture in the port cities is incorrect. In the great early modern Indian Ocean port cities many different merchant groups lived side by side. When they had contact outside their own group they used one of the lingua francas I have mentioned, but within the group their own language would obviously continue to be used. This reminds us that language differences, along with differing legal and mercantile customs, meant that in these port cities these groups had considerable autonomy. Usually they paid taxes to the ruler, and otherwise looked after their own affairs according to their own customary usages. In Melaka at the time of the Portuguese conquest in 1511 four merchant communities were important, each of them living autonomous lives with their own headmen, called shahbandars, and governing themselves with little or no reference to the ruler, the sultan. The most important of these four groups were the Gujaratis. Many were resident, but some 1,000 merchants from Gujarat visited each year. The other main groups were other merchants from the west, that is from India and especially klings from Coromandel, Malays from Indonesia and as far east as the Spice Islands and the Philippines, and the East Asians, mostly from South China but also from Japan and Okinawa. They lived in ethnically-based quarters, here called kampongs, and each group was represented before the "state" by a shahbandar. The sultan participated vigorously in trade, but apparently gave himself no particular advantage from his position as ruler. ${ }^{78}$ Similarly, in the great Gujarati ports different merchant communities had recognised leaders, though their power here, being located not in an independent port city but in

76. Ibid.

77. Moira Tampoe, Maritime Trade Between China and the West: An Archaeological Study of the Ceramics from Siraf (Persian Gulf), $8^{\text {th }}$ to $15^{\text {th }}$ Centuries A.D. (Oxford: University of Oxford Press, 1989), 124.

78. See the exemplary study by Thomaz, "Malaka et ses communautés marchandes," 31-48. 
a city which was part of a major landed state, must have been less. In Calicut there was a clear distinction, and considerable autonomy, for Gujarati Hindu merchants, foreign Muslims from various places of origin (the most important being those from the Red Sea and Cairo, known as Pardesi), and local Muslims, known as Mapillahs. "They sail everywhere with goods of many kinds and have in the town itself a Moorish Governor of their own who rules and punishes them without interference from the King, save that the Governor gives an account of certain matters to the King." 79

I prefer to leave the matter open: at the least it seems clear that a search for cosmopolitanism in early modern Indian Ocean port cities is fraught with difficulties, and needs to be undertaken with some care. It must also be stressed that merchants engaged in cut throat competition and were quite ready to use dubious means to win an advantage. As an example, the English complained of the "tyranny" of Virji Vorah (c. 1590-c. 1670s), an exceptionally wealthy Indian merchant from Surat. Could one expect men competing vigorously in the market place to at other times cast aside differences and indulge in common cultural pursuits?

My contention is that giving due weight to place, as well as our more familiar chronology, could enable us to ask new and perhaps better questions. Cabins, ecotones and port cities change over time to be sure, but an analysis of them as spaces or places can add an important dimension to our discussions.

79. Duarte Barbosa, The book of Duarte Barbosa: An Account of the Countries Bordering on the Indian Ocean and their Inhabitants, 2 vols., trans and ed. Mansel Longworth Dames (London: Hakluyt Society, 1918), 2: 76. 